\title{
Level of Psychology of Taekwondo Athletes
}

\author{
Okky Indera Pamungkas*, Risti Nurfadhilah \\ Sports Science Faculty \\ Yogyakarta State University \\ Yogyakarta, Indonesia \\ *okkyindera@uny.ac.id, risti.n@uny.ac.id
}

\begin{abstract}
Sports psychology has an important role for athletes, especially in influencing athletes' performance. So we need a test to measure the level of psychology in taekwondo athletes. This study aims to determine the level of psychology in taekwondo athletes. There were 12 respondents who filled in the complete data. This research is a descriptive study with a survey method. The results showed that the level of psychology is as follows: Results of psychological testing research minimum value $=96$; maximum value $=140$; average test results $=115.5833333$; median $=111$. The average value that is owned is that shows that the majority of the psychology level of taekwondo athletes is categorized well.
\end{abstract}

\section{Keywords: sports psychology, taekwondo, athletes}

\section{INTRODUCTION}

Sport has developed into a necessity and lifestyle for the people. Sports are carried out as an effort to gain physical fitness and health status. Sport is essentially a miniature of life. This statement implies that the basic essences of everyday human life can also be found in sports. Sport teaches discipline, sportsmanship, not giving up easily, high competitive spirit, the spirit of cooperation, and understanding of the rules and dare to make decisions to someone. Sports can be used as forming the personality and character of the nation. In addition, sport is one aspect of national pride and also a national program in Indonesia. As is often reported in various mass media currently being incessant incessantly promoting sports.

Coaching a child to be an athlete is a very hard job, therefore coaching must be done intensively and thoroughly. Knowledge and ability of a trainer are very influential in this case because a coach has the task of guiding and helping to reveal the potential of the trainees. This understanding is rooted in all aspects, from the planning of training programs to the basic techniques of a sport. With the promotion of the movement to promote sports, sports activities in the country have increased. Many types of sports that can be chosen by the community to be used as a medium of communication. One sport that is quite popular with people in Indonesia, especially in the Special Region of Yogyakarta, is taekwondo martial arts. Taekwondo in the Special Region of Yogyakarta is developing very rapidly, as evidenced by many regional and national championships that are often held, such as: Regional Student Sports, National Championship, National Student Sports.

Taekwondo self-defence sports are in great demand from childhood, adolescents, and adults to parents both sons and daughters. Taekwondo self-defence sports are achievement sports that are competed at the district, provincial, national and international levels. The purpose of holding a taekwondo competition is to increase athletes' flying hours, increase athlete achievement motivation and introduce the branch of taekwondo to the general public. In taekwondo martial arts athletes are required to have good psychological abilities, because of good psychology will be a complement of components such as physical, technical, and tactic.

Like other sports, taekwondo is a sport that requires good psychology, a psychological component that affects the athlete's component. To meet this, regular, planned, and consistent training is needed.

The element of psychology is one of the conditions used in achieving an achievement, to produce peak performance in athletes it is necessary to apply the practice of psychology as an element needed in training. The psychological condition of athletes is not stable (unstable), this is due to irregular patterns or daily habits. Factors that influence athlete psychology such as eating patterns, lack of rest, less regular exercise, and the limited ability of science and technology trainers in the methods of training athlete psychology.

Athletes who have good psychological abilities will certainly be more likely to excel. To find out whether an athlete is in a good psychological condition or not needs to do a psychological ability test, so if there are athletes whose psychology abilities are not good there will be immediate steps to improve the psychological condition for the better. To improve athlete's achievement that must be considered in developing an athlete is the availability of facilities and infrastructure, quality trainers, talented athletes, and regular competition and must be supported by adequate science and technology. By knowing the psychological condition of a taekwondo athlete, it can be predicted the athlete's ability to excel in the future. The dominant psychological component required by taekwondo athletes as a complement to other components is like speed, strength, power, flexibility, agility, and endurance. Therefore it is the duty of a coach to create good training programs to support the achievements of his athletes. Based on the results of observations made by researchers, it turns out there are no data on the psychology profile of taekwondo athletes in the Special Region of Yogyakarta.

Based on the description above, it is clear that the psychological condition is an important factor for more 
attention in coaching athletes, especially in taekwondo athletes in the Special Region of Yogyakarta. It is important to pay attention to the psychological condition of the athlete because if an athlete has an unfavourable psychological condition, it will affect his performance (performance). In the Special Region of Yogyakarta, there are many dojang (training sites) where taekwondo training athletes are scattered in all districts and cities, but trainers' knowledge on how to train psychology is very lacking because not all trainers have attended training on methods to train athlete psychology.

Based on the description above, researchers consider it important to be appointed in the form of research, especially research on the psychological condition of taekwondo athletes. Therefore, researchers intend to make a study entitled Psychology Profile of Taekwondo Athletes.

\section{METHOD}

This research is a descriptive study, one of which is that there is no hypothesis and the data collected is presented. According to Saifuddin Azwar (in Eka Septiani), descriptive research analyses only up to the description level, which is to analyse and present facts systematically so that they can be more easily understood and concluded [1]. According Syofian Siregar, descriptive research is research conducted to determine the value of an independent variable, either one or more variables (independent) without making comparisons or relationships with other variables [2].

The method used in this study is a survey method with test and measurement techniques. Survey method according to Syofian Siregar survey research is research with no changes (no special treatment) of the variables studied [2]. According to Kerlinger (in Syofian Siregar), the characteristics of survey research, as follows: 1) the object of research is large and small populations, but the data studied are data from samples taken from these populations, so that relative events, distribution, and relationships between sociological and psychological variables can be found, 2) survey research is conducted to make a generalization from in-depth observations, and 3) this survey method does not require a control group like the experimental method [2].

According to Suharsimi Arikunto states that the research variable is the object of research or what is the focus of research [3]. Sugiyono states that the research variable is everything in the form of whatever is determined by the researcher to be studied in order to obtain information about it, then conclusions are drawn [4]. The variable in this study is the psychological profile of DIY taekwondo athletes measured using IQ tests. This research was conducted in Sleman Regency. Data was collected on May 16, 2019.

\section{RESULTS AND DISCUSSION}

Psychological test results of the minimum value $=96$; maximum value $=140$; average test results $=115.5833333$; median $=111$. The results of the psychological test research can be described in the following figure:

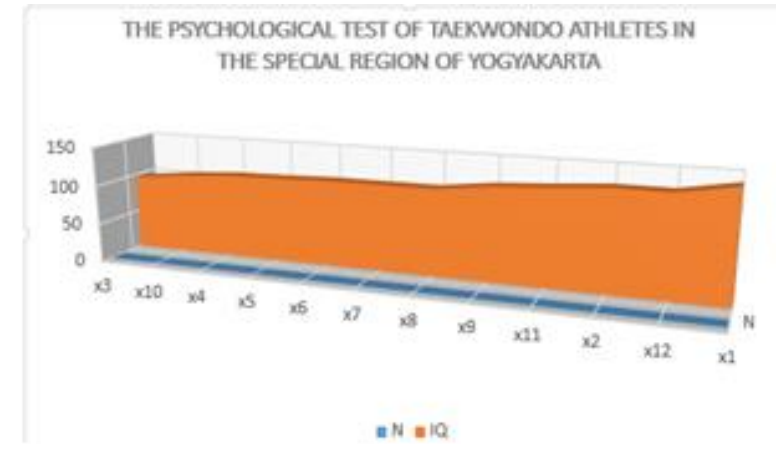

Fig. 1. Psychological test results.

The psychological level is a state of readiness to face the exercise that will be done, while the physical condition in terms of physiology is the ability of a person can be known to what extent his ability as a supporter of running sports activities. Good physical condition is really needed by an athlete or athlete, one of them is in karate. Like other sports, karate is a sport that requires good physical strength, such as strength, speed, agility, flexibility, endurance, power, and coordination in training as well as competing. To meet all this, regular, planned, and steady practice is very necessary. For that, it is necessary to know the physical profile of DIY karate athletes in order to determine future training.

Other psychological level factors such as rest, healthy living habits, environmental factors and food factors, such as age, sex, somatotype or body shape, nutritional health condition, weight and rest will also affect one's physical condition. Thus, excellent physical condition and good beside regular exercise can also be realized with adequate rest. Setting a healthy lifestyle, maintaining food intake.

\section{CONCLUSION}

For athletes who still have less physical conditions to further improve it by way of routine training. For coaches should always control the physical condition of athletes, so for those who are still lacking can be improved. For further researchers are expected to use a wider population, so that data about the physical athlete can be identified even broader.

\section{REFERENCES}

[1] E. Septiani, Profil Kondisi Fisik Anggota Survey research is conducted to make a generalization from in-depYogyakarta, Yogyakarta: Fakultas Ilmu Keolahragaan Universitas Negeri Yogyakarta, 2013.

[2] S. Siregar Statistik Parametrik Untuk Penelitian Kuantitatif, PT Bumi Aksara, 2013.

[3] S. Arikunto, Prosedur Penelitian Suatu Pendekatan Praktis, Jakarta: Rineka Cipta, 2006.

[4] Sugiyono, Metode Penelitian Pendidikan, Bandung: Alfabeta, 2010. 